\title{
Impact of Multiple Intelligence Based Intervention on Cognitive Abilities of Students
}

\author{
Hemant Nanda ${ }^{1}$, Shruti Marwaha ${ }^{2 *}$, Geetika Nanda $^{3}$ \\ ${ }^{1,2,3}$ Centre for Research in Applied Cognitive Sciences, India.
}

\begin{abstract}
ARTICLE INFO
Keywords:

creative quotient;

cognitive capacity;

estimation level;

decision making ability;

focus factor
\end{abstract}

\begin{abstract}
As an enlightening process, the principal and global intent of education is to enhance students' cognitive abilities. Cognitive abilities induce progressive attainment and retention of learning skills that enable children to apply the attained information. Cognitive abilities can be improved by providing the right training to children. An in-depth longitudinal study was conducted to analyze the impact of educational intervention based on Gardner's multiple intelligence on the cognitive abilities of the respondents. Cluster sampling was followed to extract a sample including 3500 school going boys and girls aged between 11-14 years in India. The sample was primarily categorized into experimental and control groups. Both the groups were assessed in terms of their intelligence quotient, focus factor, decision making ability, creative quotient, cognitive capacity and estimation level thrice during the timeline of 12 months. Standardized cognitive ability assessment and multiple intelligence assessment were administered on them. Experimental group availed intervention whereas the control group was excluded from intervention. Intervention was provided in form of task-sheets based on the age and respective dominant multiple intelligence of each student. Eventually, a significant surge was notified in the cognitive abilities of experimental group while there was no such noticeable change in the cognitive abilities of control group. Therefore, it was concluded that the cognitive abilities of the children can be enhanced drastically if the educational instructions are imparted through their respective dominant intelligence. Hence, the educational system can become highly productive to bestow inevitable improvement in the development of cognitive abilities among students.
\end{abstract}

\section{Introduction}

Cognition is the entire thinking process. There are five core cognitive functions that influence learning skills. These are intelligence quotient, focus factor, decision making ability, creative quotient and cognitive capacity. Intelligence is the ability of a human brain to understand, comprehend and respond to the situations in an effective and efficient way. Focus factor is an indicator for collective focus and concentration in accomplishing assigned task to the 
brain. It is one of the most prominent factors to achieve success. Decision making ability is a measurement of speed of decision making ability and response time to accomplish assigned tasks. Creative quotient is the capacity of generating ideas that can in some way be applied to the world. Cognitive capacity is the overall efficiency of your Brain. Higher the cognitive capacity better is the learner's efficiency, to store, process and retrieve information. Estimation level refers to the extent the child estimates himself. The research study was designed to cater to the needs of every individual seeking education. The content was designed, developed and delivered through educationists, experts in child development and academicians in a pre defined scientific technology. Tasksheets for intervention were based on the eight intelligences as defined by Gardner. Linguistic Intelligence is one of the most traditionally emphasized intelligences in Indian schools. Logical intelligence is the ability to analyze problems logically, work effectively with mathematical operations, and investigate issues using the scientific method. Musical intelligence is the ability to perform, compose, and appreciate musical patterns, including changes in pitch, tone, and rhythm. Kinesthetic intelligence is the ability to use the body for expression. Spatial intelligence is the ability to recognize, use, and interpret images and patterns and to reproduce objects in three dimensions. Interpersonal intelligence is the ability to understand intentions, motivations, and desires of others. Intrapersonal intelligence is the ability to understand oneself, and to interpret and appreciate one's own feelings and motivations. Naturalist intelligence is the ability to recognize and appreciate our relationship with the natural world. Dunn (1988) found that when the students are taught through their perceptual strengths and preferences, the output is highly effective. Campbell and Ramey (1994) revealed that early intervention has a positive impact on intellectual and academic achievement. Wallace (1995) conducted a research study and noticed that students perform better if the teaching process involves their learning styles. In a similar study, Jasmine (1996) found that teaching with multiple intelligences can help in improvement of their performance and abilities. Reiff (1996) has recorded that multiple intelligences based teaching and learning processes help in bridging home and school life by enhancing the capacities of students. Ellingson et al. (1997) also noticed that the student motivation increased through the use of personalized instructional and curricular adaptations. Fogarty (1997) conducted a research study and found that the problem based learning and other curriculum models for the multiple intelligences classroom motivate students to perform better. Mettetal et al. (1997)had also inferred that the students showed an accepting attitude toward a multiple intelligences curriculum and that their performance, intellectual abilities and behaviour improve when the students are imparted education through teaching style corresponding to their natural intelligence. Likewise, Kuzniewski et al. (1998) established through the empirical data, that the abilities of students improved when they were taught using their natural learning style. Gardner (2000) in his book, 'Intelligence reframed' has emphasized that each individual has the abilities which can be identified and fostered by teaching and educating them by the methodology based on their natural intelligences. Naglieri and Johnson (2000) found the effectiveness of a cognitive strategy intervention in improving scholastic achievement. Silver et al. (2000) highlighted that the 
integration of learning styles and multiple intelligences can improve the performance and build up new capabilities among the students. Teele and Teele (2000) endorsed the concept of multiple intelligences based teaching to help students explore themselves. Craft (2001) analysed the impact of creativity in education and found positive correlation. Grigoriadou et al. (2001) developed a personalized instruction and found a highly positive relation of the system on students' abilities. Similarly Haynes (2001) emphasized the importance of teaching according to students' learning styles. Carter (2002) also found that personalized training methods improve cognitive abilities. McCandliss et al. (2003) highlighted the importance of planned intervention and focusing attention for improving their performance. Nolen (2003) recorded the importance of multiple intelligence for every classroom in order to enhance students' skills and abilities. Similar findings were suggested by Stanford (2003), Sternberg and Grigorenko (2004). In a study carried by Dunbar-Hall (2006), it was inferred that educating children as per their learning styles and dominant multiple intelligence improves their abilities and grasping power. The importance of multiple intelligences has been well defined by Gardner (2008), McClellan and Conti (2008), Armstrong (2009) and Chen et al. (2009). Moreover, Cassidy et al. (2016) and Meltzer (2018) found that intervention increased general intelligence and scholastic aptitude. Barros et al. (2019) found that the perfect and realistic self estimation is important for success. Huang et al. (2019) and Rasheed and Wahid (2019) inferred that learning styles matter extremely to motivating learners for better outputs. In the light of the reviewed studies, it was important to ascertain the importance of intervention based on multiple intelligences on cognitive abilities.

\section{Methodology}

The purpose of the study was to analyze the impact of educational intervention based on Gardner's multiple intelligence on the cognitive abilities of the respondents. The present research study was a longitudinal study. Sample was extracted in two stages following the cluster sampling. In all, 3500 school going students aged between 11-14 years from India were selected.

\begin{tabular}{|l|l|}
\hline 1 & - Rapport Building and Consent of respondents \\
2 & -Administration of pre intervention test and assessment (Assessment) \\
\hline 3 & -Intervention -1 (6 months) \\
\hline 4 & -Administration of first tracker test (Tracker Test-1) \\
\hline 5 & - Intervention -2 (6 months) \\
\hline 6 & -Administration of first tracker test (Tracker Test-2) \\
\hline
\end{tabular}

Fig.1: Intervention Programme for Experimental Group 
The sample was categorized into experimental and control groups. Both the groups were assessed in terms of their intelligence quotient, focus factor, decision making ability, creative quotient, cognitive capacity and estimation level thrice during the timeline of 12 months. Standardized cognitive ability assessment and multiple intelligence assessment were administered on them. Experimental group availed intervention whereas the control group was excluded from intervention. Intervention was provided in form of task-sheets based on the age and respective dominant multiple intelligence of each student. The cognitive abilities and natural learning style were assessed by using Cognalysis, a standardized assessment developed by the authors. Proper timeline and procedure was followed during the intervention programme as evident from figure 1 and figure 2 . Figure 1 shows the intervention programme for respondents in the experimental group while figure 2 demonstrates the programme for respondents in control group. In the first stage of the programme, rapport was built with the all the respondents. In the second step, pre intervention test and assessment was administered on all the respondents after taking their consent. The researchers hypothesize that there is a positive relationship between of educational intervention based on Gardner's multiple intelligence and the cognitive abilities of the respondents in experimental group.

\begin{tabular}{|l|l|}
\hline 1 & -Rapport Building and Consent of respondents \\
\hline 2 & -Administration of pre intervention test and assessment (Assessment) \\
\hline 3 & -NO INTERVENTION \\
\hline 5 & -Administration of first tracker test (Tracker Test-1) \\
\hline 6 & - NO INTERVENTION \\
\hline
\end{tabular}

Fig.2: Programme for Control Group

The entire process was explained to the respondents. In the third step, the respondents in the experimental group were given customized tasksheets for six months. Instructions were given to attempt two tasksheets daily on regular basis. These tasksheets were different for students with different dominant multiple intelligence as assessed in step 2. But the subjects in the control group were not given any such tasksheets. After these six months, tracker test-1 was conducted on respondents of both the experimental as well as the control group. After this, subjects in experimental group were given tasksheets for next six months while no intervention was given to control group. Later tracker test- 2 was conducted on all the respondents. 


\section{Results and Discussion}

Once the data was collected, it was analyzed for drawing the relevant inferences. SPSS software was used for descriptive and inferential data analysis. The mean value of IQ1 in experimental group was 114.9 which rose to 119.11 after first intervention. The difference was found to be statistically significant with t-value of 39.5. Later, after the second intervention, the intelligence quotient further rose to 127.99. The difference was statistically significant with tvalue of 67.46 .

\subsection{Comparing intelligence quotient before and after intervention}

\begin{tabular}{|c|c|c|c|c|c|c|c|c|c|c|}
\hline \multicolumn{11}{|c|}{ Table 1: Intelligence Quotient before and after intervention } \\
\hline \multicolumn{6}{|c|}{ Experimental Group } & \multicolumn{5}{|c|}{ Control Group } \\
\hline & Mean & $\mathrm{SD}$ & \begin{tabular}{l|} 
SE \\
$M$
\end{tabular} & $\begin{array}{c}\text { t- } \\
\text { value }\end{array}$ & $\begin{array}{l}\text { Level of } \\
\text { Sig }\end{array}$ & Mean & $\mathrm{SD}$ & $\begin{array}{l}\mathrm{SE} \\
\mathrm{M}\end{array}$ & $\begin{array}{c}\text { t- } \\
\text { value }\end{array}$ & Level of Sig \\
\hline IQ & 1140 & 3.1 & 008 & \multirow{4}{*}{39.5} & \multirow{4}{*}{ Significant } & 1150 & 3.1 & 008 & \multirow{4}{*}{1.93} & \multirow{4}{*}{$\begin{array}{c}\text { Not } \\
\text { Significant }\end{array}$} \\
\hline-1 & 114.9 & 4 & 0.08 & & & 115.9 & 4 & 0.08 & & \\
\hline IQ & 119.1 & 3.1 & \multirow{2}{*}{0.08} & & & 116.1 & 3.1 & \multirow{2}{*}{0.08} & & \\
\hline-2 & 1 & 6 & & & & 1 & 6 & & & \\
\hline IQ & 119.1 & 3.1 & \multirow{2}{*}{0.08} & \multirow{4}{*}{67.46} & \multirow[t]{4}{*}{ Significant } & 116.1 & 3.1 & 008 & \multirow{4}{*}{0.04} & \multirow{4}{*}{$\begin{array}{c}\text { Not } \\
\text { Significant }\end{array}$} \\
\hline-2 & 1 & 6 & & & & 1 & 6 & 0.08 & & \\
\hline IQ & 127.9 & 4.5 & \multirow{2}{*}{0.1} & & & 115.9 & \multirow{2}{*}{4.5} & \multirow{2}{*}{0.1} & & \\
\hline-3 & 9 & 1 & & & & 4 & & & & \\
\hline IQ & \multirow{2}{*}{114.6} & 3.1 & \multirow{2}{*}{0.08} & \multirow{4}{*}{99.5} & \multirow[t]{4}{*}{ Significant } & 1150 & 3.1 & 008 & \multirow{4}{*}{0.34} & \multirow{4}{*}{$\begin{array}{c}\text { Not } \\
\text { Significant }\end{array}$} \\
\hline-1 & & 4 & & & & 115.9 & 4 & 0.08 & & \\
\hline IQ & 127.9 & 4.5 & \multirow{2}{*}{0.1} & & & 115.9 & \multirow{2}{*}{4.5} & \multirow{2}{*}{0.1} & & \\
\hline-3 & 9 & 1 & & & & 4 & & & & \\
\hline
\end{tabular}




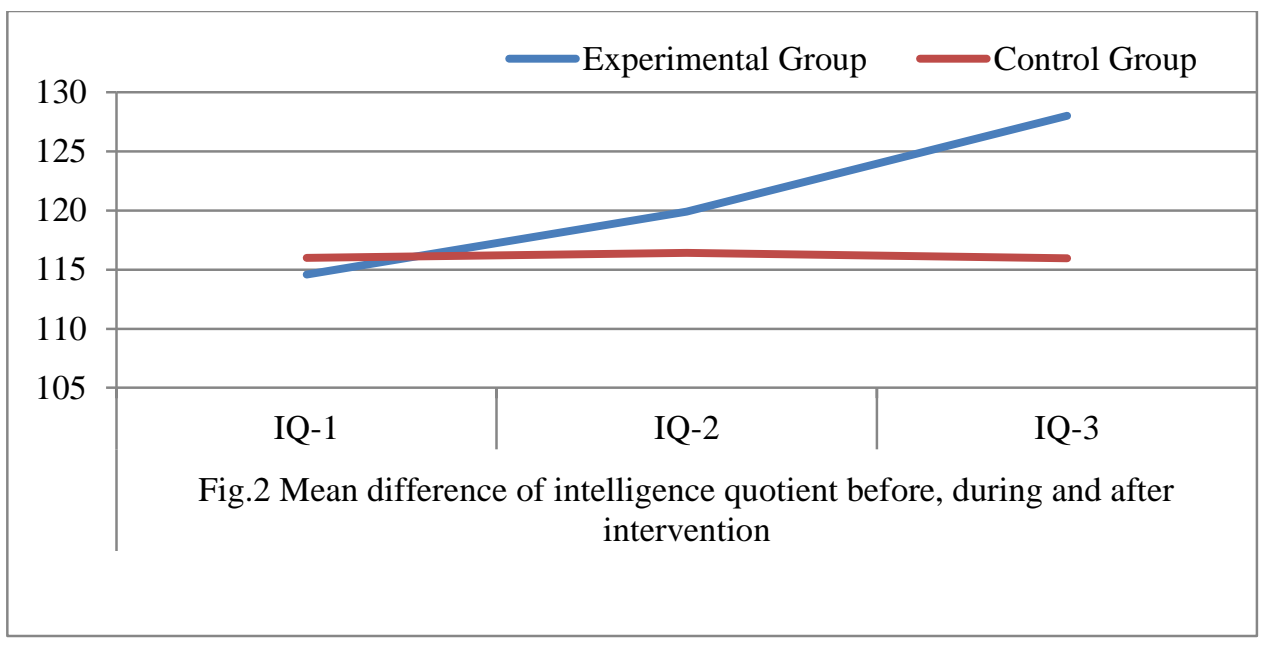

Moreover, when the mean value in test- 1 was compared with that of test- 3 , the difference was found to be statistically significant and the $t$ value was 99.5. In case of control group, no such significant difference could be found in any case. Similar findings were suggested by Blackwell et al. (2007), Diamond et al. (2007), Douglas et al. (2008), Petty (2009) and Cassidy et al. (2011).

\subsection{Comparing focus factor before and after intervention}

\begin{tabular}{|c|c|c|c|c|c|c|c|c|c|c|}
\hline \multicolumn{11}{|c|}{ Table 2: Focus Factor before and after intervention } \\
\hline \multicolumn{6}{|c|}{ Experimental Group } & \multicolumn{5}{|c|}{ Control Group } \\
\hline & $\begin{array}{l}\mathrm{Me} \\
\text { an }\end{array}$ & $\begin{array}{l}\mathrm{S} \\
\mathrm{D}\end{array}$ & $\begin{array}{l}\text { SE } \\
M\end{array}$ & $\begin{array}{c}\mathrm{t}- \\
\text { valu } \\
\mathrm{e}\end{array}$ & $\begin{array}{l}\text { Level of } \\
\text { Sig }\end{array}$ & $\begin{array}{l}\mathrm{Me} \\
\text { an }\end{array}$ & $\begin{array}{l}\text { S } \\
\mathrm{D}\end{array}$ & $\begin{array}{l}\text { SE } \\
M\end{array}$ & $\begin{array}{c}\mathrm{t}- \\
\text { valu } \\
\mathrm{e}\end{array}$ & $\begin{array}{c}\text { Level of } \\
\text { Sig }\end{array}$ \\
\hline $\begin{array}{l}F \\
F \\
-1\end{array}$ & $\begin{array}{c}75 . \\
9\end{array}$ & $\begin{array}{c}6 . \\
05\end{array}$ & $\begin{array}{c}0.1 \\
4\end{array}$ & \multirow{2}{*}{$\begin{array}{c}34.9 \\
1\end{array}$} & \multirow{2}{*}{$\begin{array}{c}\text { Signific } \\
\text { ant }\end{array}$} & 79 & $\begin{array}{l}6 . \\
05\end{array}$ & 0.1 & \multirow{2}{*}{0.89} & \multirow{2}{*}{$\begin{array}{c}\text { Not } \\
\text { Significan } \\
\mathrm{t}\end{array}$} \\
\hline $\begin{array}{l}F \\
F \\
-2\end{array}$ & $\begin{array}{l}83 . \\
96\end{array}$ & $\begin{array}{c}7 . \\
27\end{array}$ & $\begin{array}{c}0.1 \\
7\end{array}$ & & & $\begin{array}{c}79 . \\
2\end{array}$ & $\begin{array}{l}7 . \\
2\end{array}$ & $\begin{array}{c}0.1 \\
7\end{array}$ & & \\
\hline $\begin{array}{l}\mathrm{F} \\
F \\
-2\end{array}$ & $\begin{array}{l}83 . \\
96\end{array}$ & $\begin{array}{l}7 . \\
27\end{array}$ & $\begin{array}{c}0.1 \\
7\end{array}$ & $\begin{array}{c}59.5 \\
1\end{array}$ & $\begin{array}{c}\text { Signific } \\
\text { ant }\end{array}$ & $\begin{array}{c}79 . \\
2\end{array}$ & $\begin{array}{l}7 . \\
2\end{array}$ & $\begin{array}{c}0.1 \\
7\end{array}$ & 1.3 & $\begin{array}{c}\text { Not } \\
\text { Significan } \\
\mathrm{t}\end{array}$ \\
\hline
\end{tabular}




\begin{tabular}{|c|c|c|c|c|c|c|c|c|c|c|}
\hline $\begin{array}{l}F \\
F \\
-3\end{array}$ & 102 & $\begin{array}{l}10 \\
.3\end{array}$ & $\begin{array}{c}0.2 \\
4\end{array}$ & & & $\begin{array}{c}79 . \\
6\end{array}$ & $\begin{array}{l}10 \\
.3\end{array}$ & $\begin{array}{c}0.2 \\
4\end{array}$ & & \\
\hline \begin{tabular}{l|}
$F$ \\
$F$ \\
-1
\end{tabular} & $\begin{array}{c}75 . \\
9\end{array}$ & $\begin{array}{c}6 . \\
05\end{array}$ & $\begin{array}{c}0.1 \\
4\end{array}$ & \multirow[t]{2}{*}{90.5} & \multirow{2}{*}{$\begin{array}{c}\text { Signific } \\
\text { ant }\end{array}$} & 79 & $\begin{array}{c}6 . \\
05\end{array}$ & 0.1 & \multirow[t]{2}{*}{1.95} & \multirow{2}{*}{$\begin{array}{c}\text { Not } \\
\text { Significan } \\
\mathrm{t}\end{array}$} \\
\hline $\begin{array}{c}F \\
F \\
-3\end{array}$ & 102 & $\begin{array}{l}10 \\
.3\end{array}$ & $\begin{array}{c}0.2 \\
4\end{array}$ & & & $\begin{array}{c}79 . \\
6\end{array}$ & $\begin{array}{r}10 \\
.3\end{array}$ & $\begin{array}{c}0.2 \\
4\end{array}$ & & \\
\hline
\end{tabular}

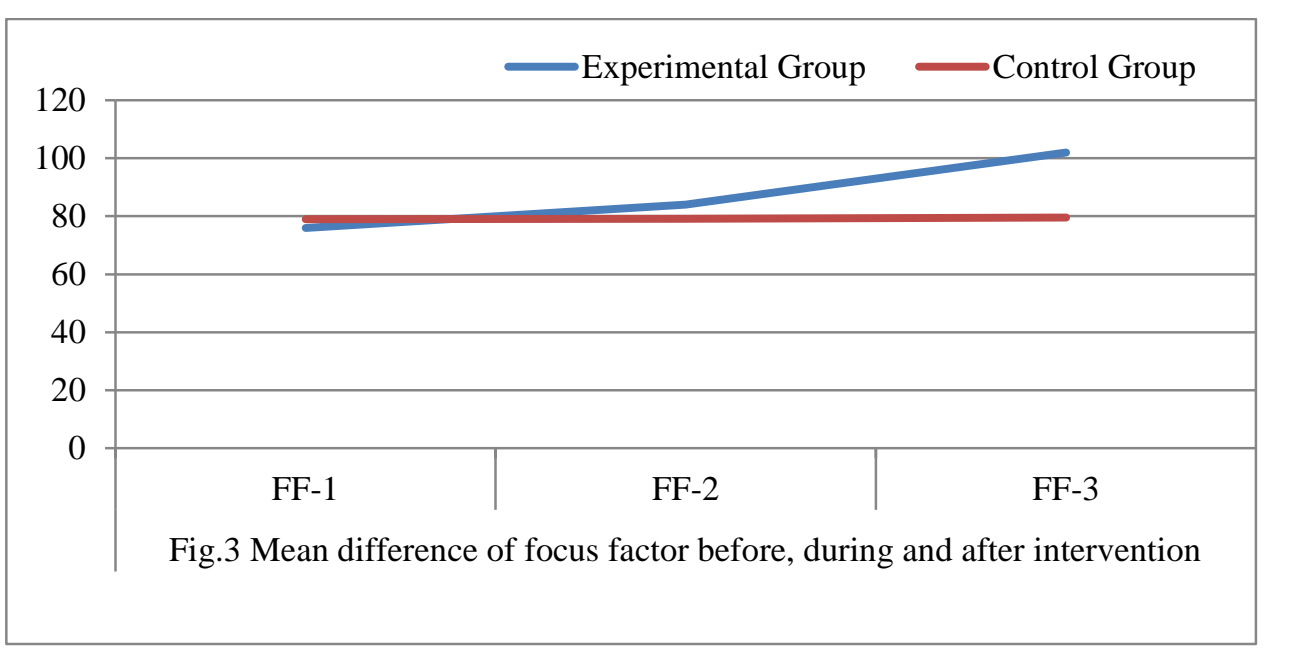

The mean value of FF1 in experimental group was 75.9 which rose to 83.96 after first intervention. The difference was found to be statistically significant with t-value of 34.91. Later, after the second intervention, the focus factor further rose to 102 . The difference was statistically significant with t-value of 59.51. Moreover, when the mean value in test- 1 was compared with that of test-3, the difference was found to be statistically significant and the $t$ value was 90.5 . On the contrary, insignificant changes were found in the focus factor of respondents in the control group. The studies conducted by Chiesa et al. (2011) and Delgoshaei and Delavari (2012) also corroborated the findings of the present study. 


\subsection{Comparing decision making ability before and after intervention}

\begin{tabular}{|c|c|c|c|c|c|c|c|c|c|c|}
\hline \multicolumn{11}{|c|}{ Table 3: Decision Making Ability before and after intervention } \\
\hline \multicolumn{6}{|c|}{ Experimental Group } & \multicolumn{5}{|c|}{ Control Group } \\
\hline & $\begin{array}{l}\mathrm{Me} \\
\text { an }\end{array}$ & $\mathrm{SD}$ & $\begin{array}{l}\text { SE } \\
\text { M }\end{array}$ & $\begin{array}{c}\mathrm{t}^{\mathrm{t}} \\
\text { valu } \\
\mathrm{e}\end{array}$ & $\begin{array}{l}\text { Level } \\
\text { of Sig }\end{array}$ & $\begin{array}{c}\mathrm{Me} \\
\text { an }\end{array}$ & SD & $\begin{array}{l}\text { SE } \\
M\end{array}$ & $\begin{array}{c}\mathrm{t}- \\
\text { valu } \\
\mathrm{e}\end{array}$ & $\begin{array}{l}\text { Level } \\
\text { of Sig }\end{array}$ \\
\hline DM & 0.3 & 0.1 & 0.0 & \multirow{4}{*}{$\begin{array}{c}20.7 \\
2\end{array}$} & \multirow{4}{*}{$\begin{array}{c}\text { Signific } \\
\text { ant }\end{array}$} & 0.4 & 0.1 & 0.00 & \multirow{4}{*}{1.81} & \multirow{4}{*}{$\begin{array}{c}\text { Not } \\
\text { Signifi } \\
\text { cant }\end{array}$} \\
\hline A-1 & 5 & 4 & 03 & & & 4 & 42 & 35 & & \\
\hline DM & 0.4 & 0.1 & 0.0 & & & 0.4 & 0.1 & 0.00 & & \\
\hline A-2 & 4 & 4 & 03 & & & 5 & 43 & 34 & & \\
\hline $\mathrm{DM}$ & 0.4 & 0.1 & 0.0 & \multirow{4}{*}{$\begin{array}{c}49.1 \\
1\end{array}$} & \multirow{4}{*}{$\begin{array}{c}\text { Signific } \\
\text { ant }\end{array}$} & 0.4 & 0.1 & 0.00 & \multirow{4}{*}{1.6} & \multirow{4}{*}{$\begin{array}{c}\text { Not } \\
\text { Signifi } \\
\text { cant }\end{array}$} \\
\hline A-2 & 4 & 4 & 03 & & & 5 & 43 & 34 & & \\
\hline DM & 0.6 & 0.1 & 0.0 & & & 0.4 & 0.1 & 0.14 & & \\
\hline A-3 & 88 & 42 & 03 & & & 6 & 42 & 4 & & \\
\hline DM & 0.3 & 0.1 & 0.0 & \multirow{4}{*}{$\begin{array}{c}69.2 \\
9\end{array}$} & \multirow{4}{*}{$\begin{array}{c}\text { Signific } \\
\text { ant }\end{array}$} & 0.4 & 0.1 & 0.00 & \multirow{4}{*}{1.72} & \multirow{4}{*}{$\begin{array}{c}\text { Not } \\
\text { Signifi } \\
\text { cant }\end{array}$} \\
\hline A-1 & 5 & 4 & 03 & & & 4 & 42 & 35 & & \\
\hline DM & 0.6 & 0.1 & 0.0 & & & 0.4 & 0.1 & 0.14 & & \\
\hline A-3 & 88 & 42 & 03 & & & 6 & 42 & 4 & & \\
\hline
\end{tabular}

The mean value of DMA1 in experimental group was 0.35 which rose to 0.44 after first intervention. The difference was found to be statistically significant with t-value of 20.72. Later, after the second intervention, the decision making ability further rose to 0.688 . The difference was statistically significant with t-value of 49.11. As the mean value in test- 1 was compared with that of test- 3 , the difference was found to be statistically significant and the $t$ value was 69.29. In contrast, insignificant changes were found in case of their control group counterparts. Morewedge et al. (2015) found the similar results 


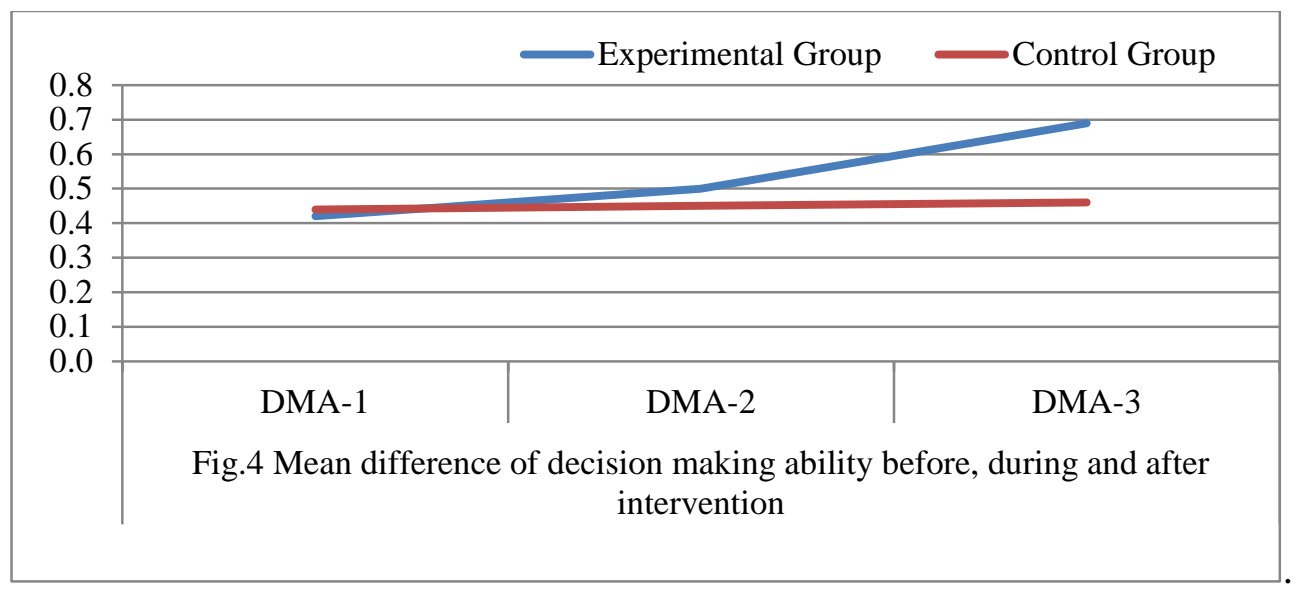

1.4 Comparing creative quotient before and after intervention

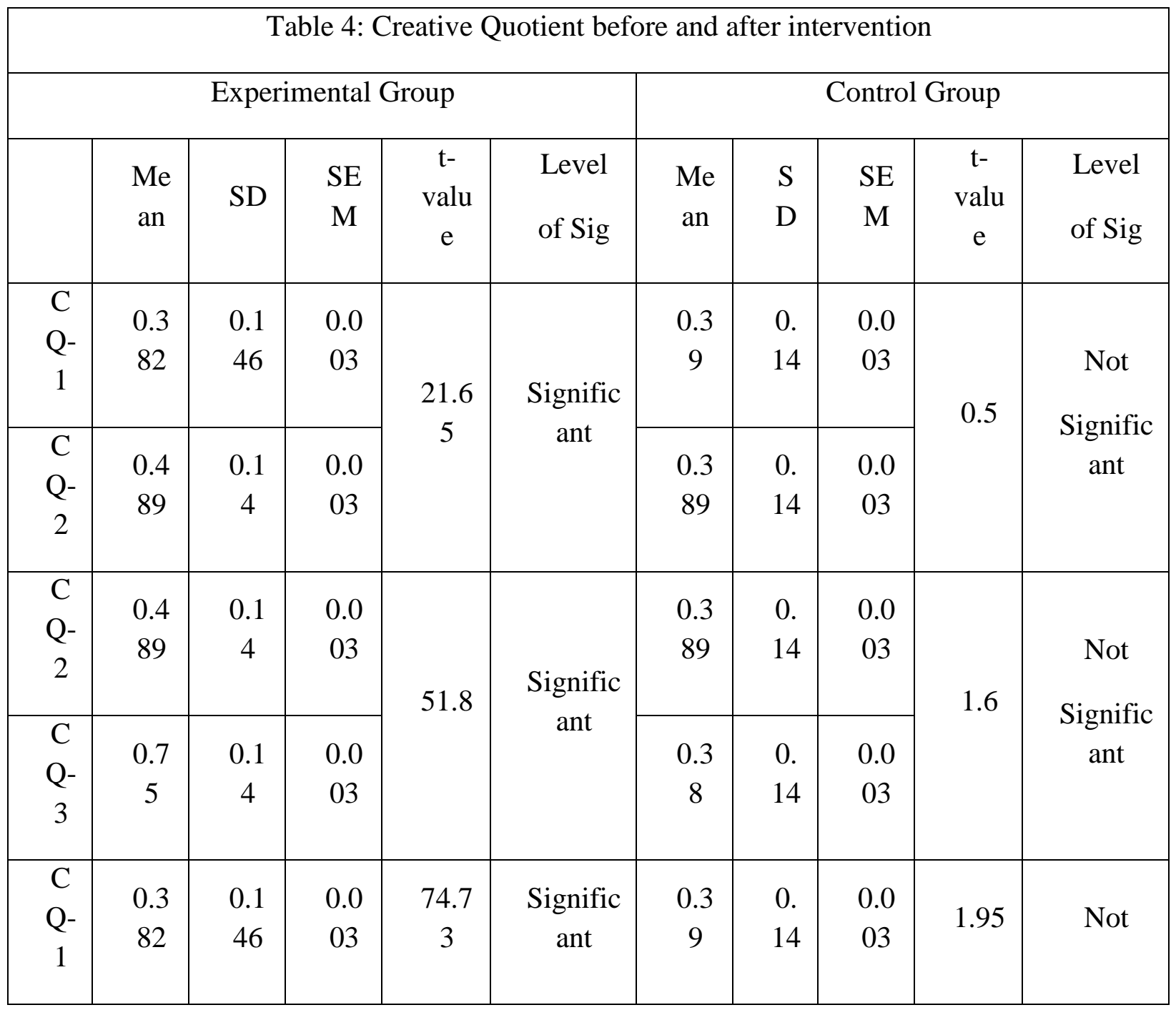




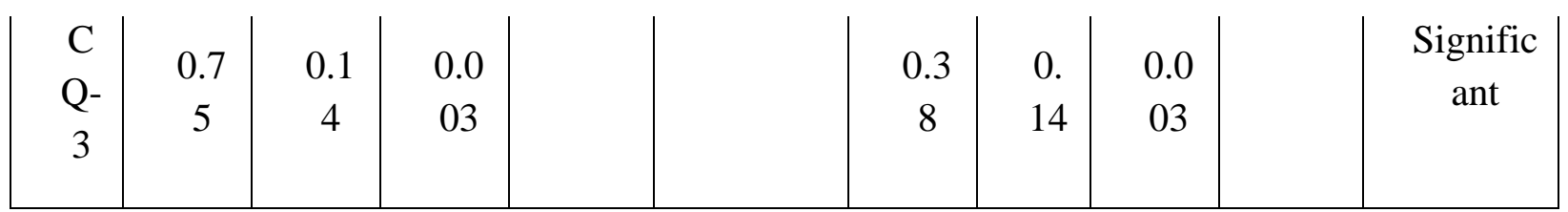

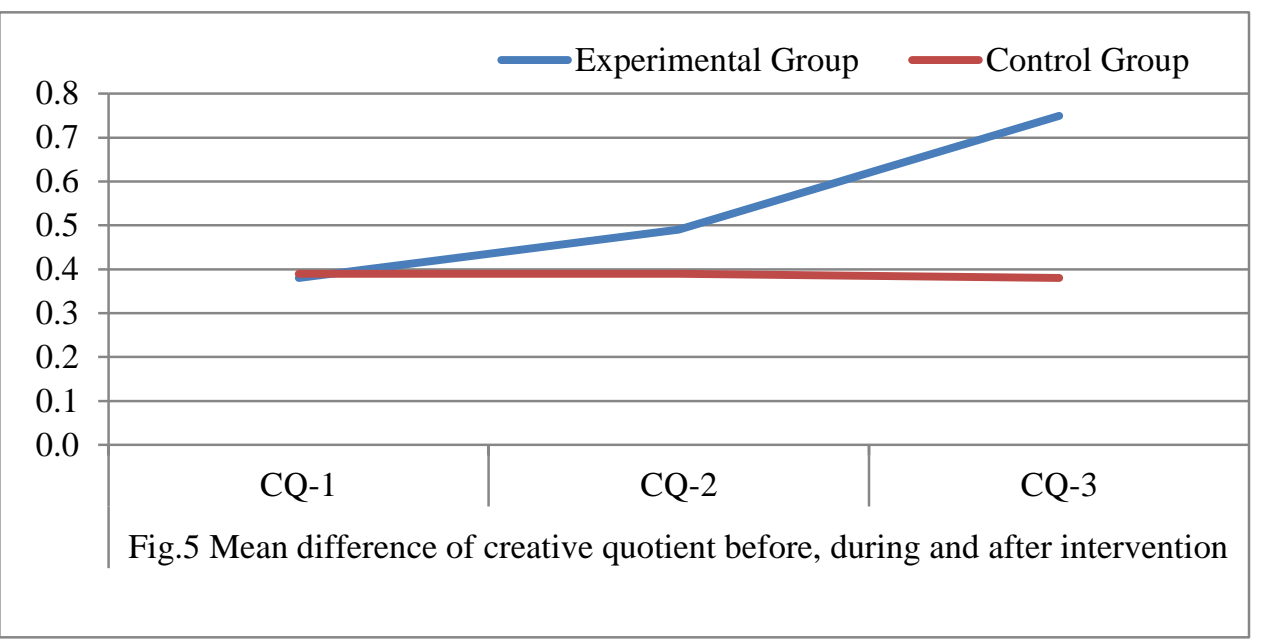

The mean value of CQ1 in experimental group was 0.382 which rose to 0.489 after first intervention. The difference was found to be statistically significant with t-value of 21.65. Later, after the second intervention, the creative quotient further rose to 0.75 . The difference was statistically significant with t-value of 51.8. Moreover, when the mean value in test-1 was compared with that of test-3, the difference was found to be statistically significant and the $\mathrm{t}$ value was 74.73. However, insignificant changes were found in the creative quotient of students in control group. Similar findings were suggested by $\mathrm{Hu}$ et al. (2013).

\subsection{Comparing cognitive capacity before and after intervention}

\begin{tabular}{|c|c|c|c|c|c|c|c|c|c|c|}
\hline \multicolumn{11}{|c|}{ Table 5: Cognitive Capacity before and after intervention } \\
\hline \multicolumn{6}{|c|}{ Experimental Group } & \multicolumn{5}{|c|}{ Control Group } \\
\hline & $\begin{array}{c}\mathrm{Me} \\
\text { an }\end{array}$ & $\mathrm{SD}$ & $\begin{array}{l}\mathrm{SE} \\
\mathrm{M}\end{array}$ & $\begin{array}{c}\mathrm{t}- \\
\text { val } \\
\text { ue }\end{array}$ & $\begin{array}{l}\text { Level } \\
\text { of Sig }\end{array}$ & $\begin{array}{c}\mathrm{Me} \\
\text { an }\end{array}$ & SD & $\begin{array}{l}\text { SE } \\
M\end{array}$ & $\begin{array}{l}\mathrm{t}- \\
\text { val } \\
\text { ue }\end{array}$ & $\begin{array}{c}\text { Level of } \\
\text { Sig }\end{array}$ \\
\hline $\begin{array}{l}C \\
C \\
-1\end{array}$ & $\begin{array}{c}0.6 \\
1\end{array}$ & $\begin{array}{l}0.1 \\
45\end{array}$ & $\begin{array}{r}0.0 \\
035\end{array}$ & $\begin{array}{l}16 . \\
99\end{array}$ & $\begin{array}{c}\text { Signific } \\
\text { ant }\end{array}$ & $\begin{array}{c}0.6 \\
2\end{array}$ & $\begin{array}{l}0.1 \\
45\end{array}$ & $\begin{array}{l}0.0 \\
035\end{array}$ & $\begin{array}{c}0.9 \\
2\end{array}$ & $\begin{array}{c}\text { Not } \\
\text { Significa } \\
\text { nt }\end{array}$ \\
\hline
\end{tabular}




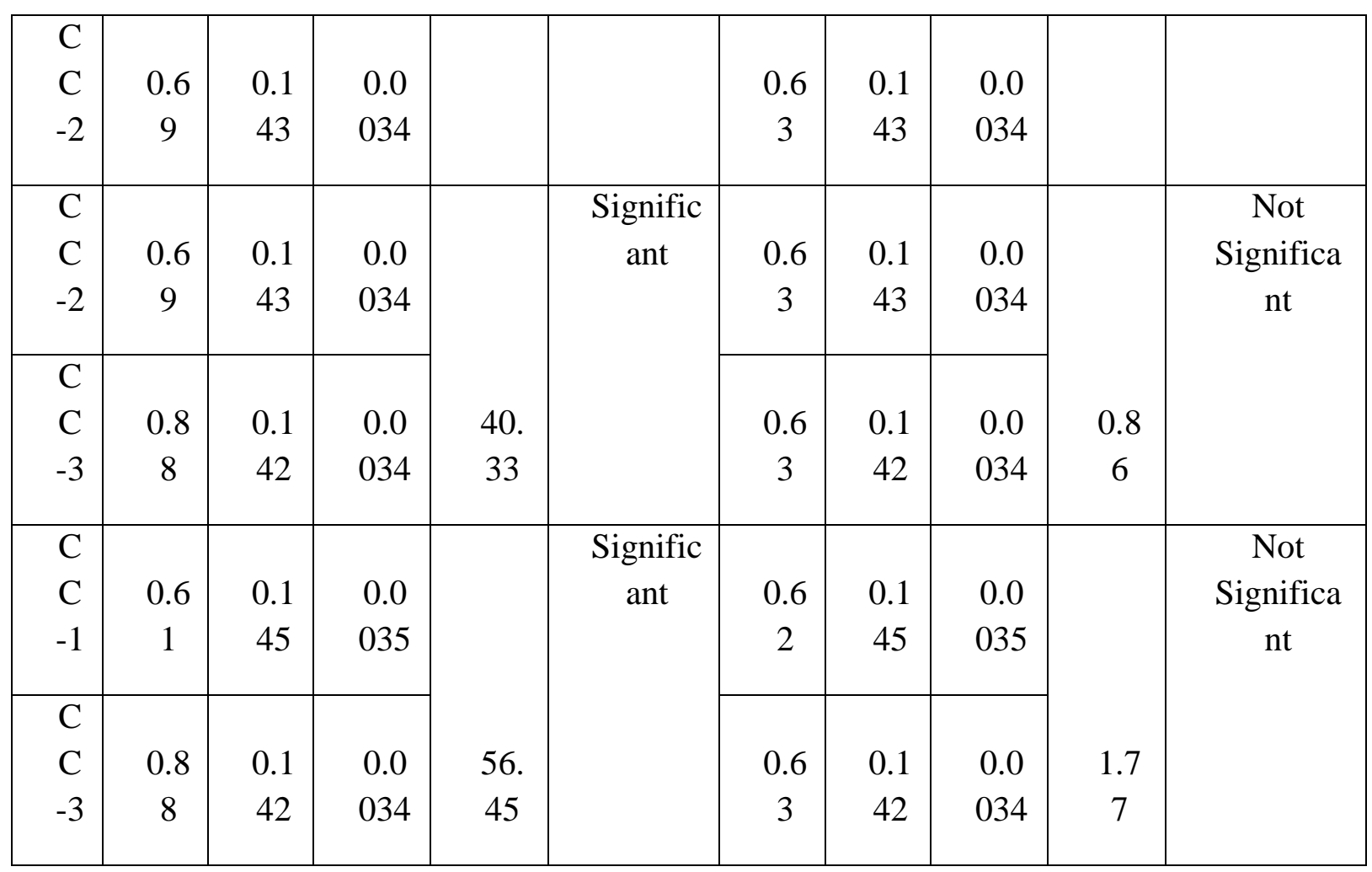

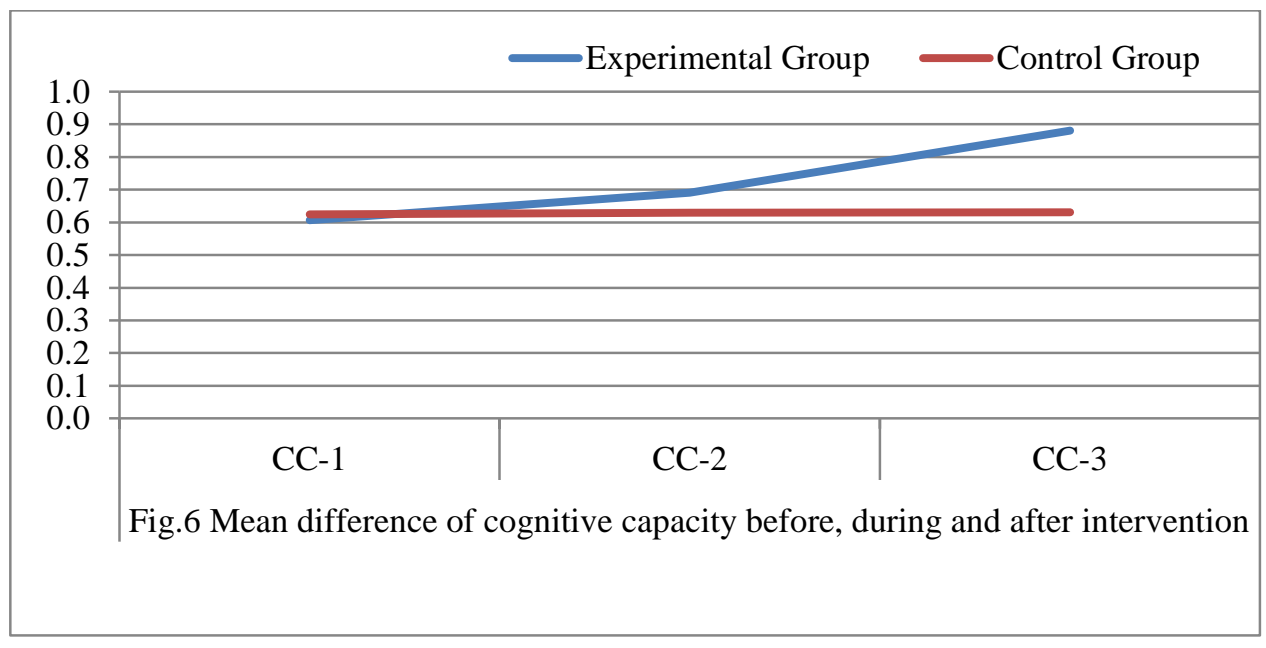

The mean value of $\mathrm{CC} 1$ in experimental group was 0.61 which rose to 0.69 after first intervention. The difference was found to be statistically significant with t-value of 16.99. Later, after the second intervention, the cognitive capacity further rose to 0.88 . The difference was statistically significant with t-value of 40.33 . Moreover, when the mean value in test- 1 was compared with that of test- 3 , the difference was found to be statistically significant and the $t$ value was 56.45. However, insignificant changes were found in the cognitive capacity of respondents in control group. The findings were similar to that inferred by Kerry (2015). 


\subsection{Comparing estimation level before and after intervention}

\begin{tabular}{|c|c|c|c|c|c|c|c|c|c|c|}
\hline \multicolumn{11}{|c|}{ Table 6: Estimation Level before and after intervention } \\
\hline \multicolumn{6}{|c|}{ Experimental Group } & \multicolumn{5}{|c|}{ Control Group } \\
\hline & $\begin{array}{c}\mathrm{Me} \\
\text { an }\end{array}$ & $\begin{array}{l}\mathrm{S} \\
\mathrm{D}\end{array}$ & $\begin{array}{l}\text { SE } \\
M\end{array}$ & $\begin{array}{c}\mathrm{t}- \\
\text { valu } \\
\mathrm{e}\end{array}$ & $\begin{array}{l}\text { Level of } \\
\text { Sig }\end{array}$ & $\begin{array}{c}\mathrm{Me} \\
\text { an }\end{array}$ & $\begin{array}{l}\mathrm{S} \\
\mathrm{D}\end{array}$ & $\begin{array}{l}\text { SE } \\
M\end{array}$ & $\begin{array}{c}\mathrm{t}- \\
\text { valu } \\
\mathrm{e}\end{array}$ & $\begin{array}{l}\text { Level of } \\
\text { Sig }\end{array}$ \\
\hline $\begin{array}{c}\mathrm{E} \\
\mathrm{L} \\
-1\end{array}$ & $\begin{array}{c}50 . \\
12\end{array}$ & $\begin{array}{c}2 . \\
02\end{array}$ & $\begin{array}{c}0.0 \\
5\end{array}$ & \multirow[t]{2}{*}{0.67} & \multirow{2}{*}{$\begin{array}{c}\text { Not } \\
\text { Significan } \\
\mathrm{t}\end{array}$} & 51 & $\begin{array}{c}2 . \\
02\end{array}$ & $\begin{array}{c}0.0 \\
5\end{array}$ & \multirow[t]{2}{*}{0.71} & \multirow{2}{*}{$\begin{array}{c}\text { Not } \\
\text { Significan } \\
\mathrm{t}\end{array}$} \\
\hline $\begin{array}{l}\mathrm{E} \\
\mathrm{L} \\
-2\end{array}$ & $\begin{array}{c}50 . \\
13\end{array}$ & $\begin{array}{c}1 . \\
99\end{array}$ & $\begin{array}{c}0.0 \\
5\end{array}$ & & & $\begin{array}{c}51 . \\
19\end{array}$ & $\begin{array}{c}1 . \\
99\end{array}$ & $\begin{array}{c}0.0 \\
5\end{array}$ & & \\
\hline $\begin{array}{l}\mathrm{E} \\
\mathrm{L} \\
-2\end{array}$ & $\begin{array}{c}50 . \\
13\end{array}$ & $\begin{array}{l}1 . \\
99\end{array}$ & $\begin{array}{c}0.0 \\
5\end{array}$ & \multirow[t]{2}{*}{1.89} & \multirow{2}{*}{$\begin{array}{c}\text { Not } \\
\text { Significan } \\
\mathrm{t}\end{array}$} & $\begin{array}{c}51 . \\
19\end{array}$ & $\begin{array}{c}1 . \\
99\end{array}$ & $\begin{array}{c}0.0 \\
5\end{array}$ & \multirow[t]{2}{*}{0.58} & \multirow{2}{*}{$\begin{array}{c}\text { Not } \\
\text { Significan } \\
\mathrm{t}\end{array}$} \\
\hline $\begin{array}{l}E \\
L \\
-3\end{array}$ & $\begin{array}{c}50 . \\
1\end{array}$ & $\begin{array}{l}1 . \\
97\end{array}$ & $\begin{array}{c}0.0 \\
5\end{array}$ & & & $\begin{array}{l}51 . \\
21\end{array}$ & $\begin{array}{l}1 . \\
99\end{array}$ & $\begin{array}{c}0.0 \\
5\end{array}$ & & \\
\hline $\begin{array}{l}\mathrm{E} \\
\mathrm{L} \\
-1\end{array}$ & $\begin{array}{c}50 . \\
12\end{array}$ & $\begin{array}{l}2 . \\
02\end{array}$ & $\begin{array}{c}0.0 \\
5\end{array}$ & \multirow[t]{2}{*}{1.95} & \multirow{2}{*}{$\begin{array}{c}\text { Not } \\
\text { Significan } \\
\mathrm{t}\end{array}$} & 51 & $\begin{array}{c}2 . \\
02\end{array}$ & $\begin{array}{c}0.0 \\
5\end{array}$ & \multirow[t]{2}{*}{1.96} & \multirow{2}{*}{$\begin{array}{c}\text { Not } \\
\text { Significan } \\
\mathrm{t}\end{array}$} \\
\hline $\begin{array}{l}\mathrm{E} \\
\mathrm{L} \\
-3\end{array}$ & $\begin{array}{c}50 . \\
1\end{array}$ & $\begin{array}{l}1 . \\
97\end{array}$ & $\begin{array}{c}0.0 \\
5\end{array}$ & & & $\begin{array}{l}51 . \\
21\end{array}$ & $\begin{array}{c}1 . \\
99\end{array}$ & $\begin{array}{c}0.0 \\
5\end{array}$ & & \\
\hline
\end{tabular}




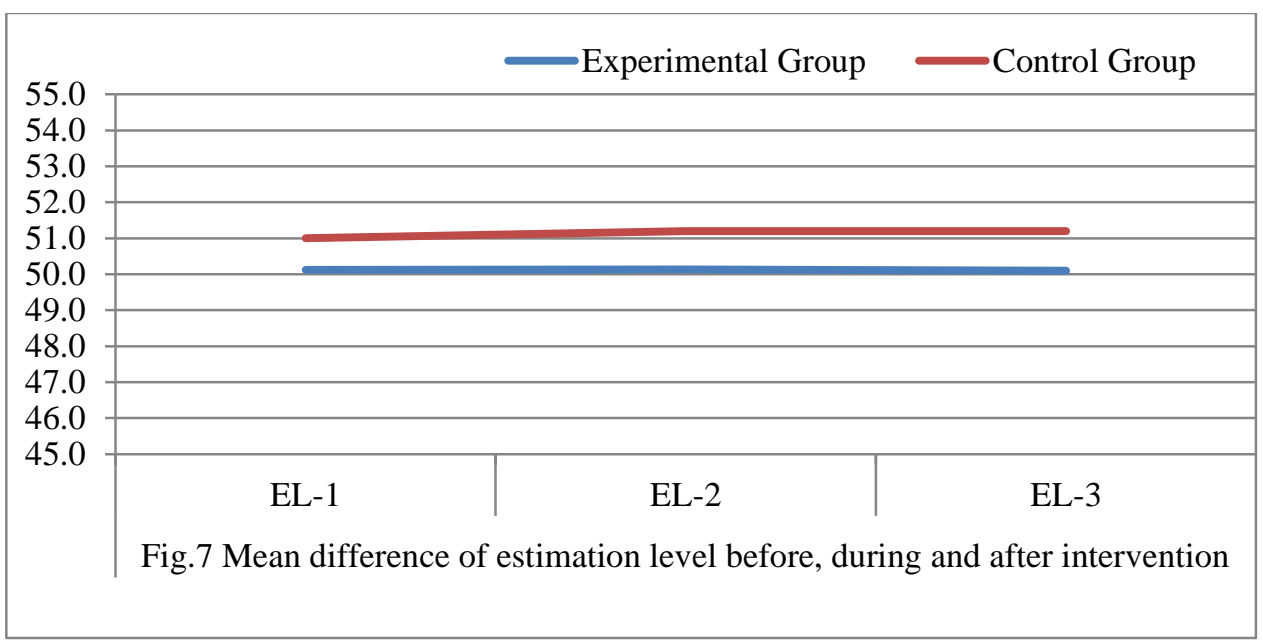

The mean value of EL1 in experimental group was 50.12 which rose to 50.13 after first intervention. The difference was found to be statistically non-significant with t-value of 0.67. Later, after the second intervention, the estimation level dipped to 50.1. The difference was insignificant with t-value of 1.89 . Moreover, when the mean value in test-1 was compared with that of test-3, the difference was found to be insignificant and the t value was 1.95. Similar trend was notified among subjects in control group.

\section{Conclusion}

Education is a tool that aids in overall development of every child. Multiple intelligence based teaching ensures holistic development of children. A personalized approach to multiple intelligence based instructions can have a direct impact on students' learning. Students' performance rise if they are engaged in activities linked to their natural interest, strengths and interests based on Gardner's multiple intelligence through the programmed instructions as per child's learning nature, In this sense, teachers can utilize the individual strengths of students for better learning. Students are benefited from choosing how they learn. Learning and cognition can be developed using natural learning style as it can cater to the diverse learning needs of all students. After the analysis of the data, it was found that if the students are taught according to their inherent primary learning style, they can learn in an efficient manner and the performance is higher as compared to the system where they are taught in the same traditional way. Hypothesis was thus proved that with the regular intervention based on multiple intelligences, their intelligence quotient, focus factor, decision making ability, creative quotient, and cognitive capacity boomed dramatically. Hence, the present research study underlines the effectiveness of teaching learning process that corresponds to each student's natural learning style. 


\section{Limitations and Further Research Implications}

The study was however limited to the cognitive aspects. The socio-demographic data was not collected due to unwillingness of the respondents and their parents. The further research study can be carried to correlate the data to the socio-demography of respondents.

\section{References}

- Armstrong, T. (2009). Multiple intelligences in the classroom. Ascd.

- Barros, J. A., Yantha, Z. D., Carter, M. J., Hussien, J., \& Ste-Marie, D. M. (2019). Examining the impact of error estimation on the effects of self-controlled feedback. Human movement science, 63, 182-198.

- Blackwell, L.S., Trzesniewski, K.H., \& Dweck, C.S. (2007). Implicit theories of intelligence predict achievement across an adolescent transition: a longitudinal study and an intervention. Child development, 78 1, 246-63.

- Campbell, F. A., \& Ramey, C. T. (1994). Effects of early intervention on intellectual and academic achievement: a follow-up study of children from low-income families. Child development, 65(2), 684-698.

- Carter, S. D. (2002). Matching training methods and factors of cognitive ability: A means to improve training outcomes. Human Resource Development Quarterly, 13(1), 71-88.

- Cassidy, S., Roche, B., \& Hayes, S. C. (2011). A relational frame training intervention to raise intelligence quotients: A pilot study. The Psychological Record, 61(2), 173-198.

- Cassidy, S., Roche, B., Colbert, D., Stewart, I., \& Grey, I. M. (2016). A relational frame skills training intervention to increase general intelligence and scholastic aptitude. Learning and Individual Differences, 47, 222-235.

- Chen, J. Q., Moran, S., \& Gardner, H. (2009). Multiple intelligences around the world. John Wiley \& Sons.

- Chiesa, A., Calati, R., \& Serretti, A. (2011). Does mindfulness training improve cognitive abilities? A systematic review of neuropsychological findings. Clinical psychology review, 31(3), 449-464.

- Craft, A. (2001). An analysis of research and literature on creativity in education. Qualifications and Curriculum Authority, 1-37.

- Delgoshaei, Y., \& Delavari, N. (2012). Applying multiple-intelligence approach to education and analyzing its impact on cognitive development of pre-school children. Procedia-Social and Behavioral Sciences, 32, 361-366.

- Diamond, A., Barnett, W. S., Thomas, J., \& Munro, S. (2007). Preschool program improves cognitive control. Science (New York, NY), 318(5855), 1387.

- Douglas, O., Burton, K. S., \& Reese-Durham, N. (2008). The effects of the multiple intelligence teaching strategy on the academic achievement of eighth grade math students. Journal of instructional psychology, 35(2). 
- Dunbar-Hall, P. (2006). An investigation of strategies developed by music learners in a crosscultural setting. Research Studies in Music Education, 26(1), 63-70.

- Dunn, R. (1988). Commentary: Teaching students through their perceptual strengths or preferences. Journal of Reading, 31(4), 304-309.

- Ellingson, W. E., Long, E. A., \& McCullough, K. L. (1997). Improving Student Motivation through the Use of Varied Instructional and Curricular Adaptations.

- Fogarty, R. (1997). Problem-based learning and other curriculum models for the multiple intelligences classroom. IRI/Skylight Training and Publishing, Inc., 2626 South Clearbrook Drive, Arlington Heights, IL 60005.

- Gardner, H. E. (2000). Intelligence reframed: Multiple intelligences for the 21 st century. Hachette UK.

- Gardner, H. E. (2008). Multiple intelligences: New horizons in theory and practice. Basic books.

- Grigoriadou, M., Papanikolaou, K., Kornilakis, H., \& Magoulas, G. (2001, July). INSPIRE: an intelligent system for personalized instruction in a remote environment. In Proceedings of $3 r d$ Workshop on Adaptive Hypertext and Hypermedia (pp. 13-24).

- Haynes, J. (2001). Teach to students' learning styles. Retrieved from htrp: llwww. everythingesl. netlinserviceslleamingstylephp.

- Hu, W., Wu, B., Jia, X., Yi, X., Duan, C., Meyer, W., \& Kaufman, J. C. (2013). Increasing students' scientific creativity: The "learn to think" intervention program. The Journal of Creative Behavior, 47(1), 3-21.

- Huang, T. C., Chen, M. Y., \& Hsu, W. P. (2019). Do Learning Styles Matter? Motivating Learners in an Augmented Geopark. Journal of Educational Technology \& Society, 22(1), 7081.

- Jasmine, J. (1996). Teaching with Multiple Intelligences. Professional's Guide. Teacher Created Materials, Inc., 6421 Industry Way, Westminster, CA 92683 (TCM822: \$8.95 plus shipping/handling)..

- Kerry, T. (2015). Learning, cognition and cross-curricular teaching. In Cross-Curricular Teaching in the Primary School(pp. 50-64). Routledge.

- Kuzniewski, F., Sanders, M., Smith, G. S., Swanson, S., \& Urich, C. (1998). Using Multiple Intelligences to Increase Reading Comprehension in English and Math.

- McCandliss, B., Beck, I. L., Sandak, R., \& Perfetti, C. (2003). Focusing attention on decoding for children with poor reading skills: Design and preliminary tests of the word building intervention. Scientific studies of reading, 7(1), 75-104.

- McClellan, J. A., \& Conti, G. J. (2008). Identifying the multiple intelligences of your students. Journal of Adult Education, 37(1), 13-32.

- Meltzer, L. (Ed.). (2018). Executive function in education: From theory to practice. Guilford Publications.

- Mettetal, G., Jordan, C., \& Harper, S. (1997). Attitudes toward a multiple intelligences curriculum. The Journal of Educational Research, 91(2), 115-122. 
- Morewedge, C. K., Yoon, H., Scopelliti, I., Symborski, C. W., Korris, J. H., \& Kassam, K. S. (2015). Debiasing decisions: Improved decision making with a single training intervention. Policy Insights from the Behavioral and Brain Sciences, 2(1), 129-140.

- Naglieri, J. A., \& Johnson, D. (2000). Effectiveness of a cognitive strategy intervention in improving arithmetic computation based on the PASS theory. Journal of learning disabilities, 33(6), 591-597.

- Nolen, J. L. (2003). MULTIPLE INTELLIGENCES IN THE CLASSROOM. Education, 124(1).

- Petty, G. (2009). Evidence-based teaching: A practical approach. Nelson Thornes.

- Rasheed, F., \& Wahid, A. (2019). Learning Style Recognition: A Neural Network Approach. In First International Conference on Artificial Intelligence and Cognitive Computing (pp. 301312). Springer, Singapore.

- Reiff, J. C. (1996). Bridging home and school through multiple intelligences. Childhood Education, 72(3), 164-166.

- Silver, H. F., Strong, R. W., \& Perini, M. J. (2000). So each may learn: Integrating learning styles and multiple intelligences. Association for Supervision and Curriculum Development, 1703 North Beauregard Street, Alexandria, VA 22311-1714.

- Stanford, P. (2003). Multiple intelligence for every classroom. Intervention in school and clinic, 39(2), 80-85.

- Sternberg, R. J., \& Grigorenko, E. L. (2004). Successful intelligence in the classroom. Theory into practice, 43(4), 274-280.

- Teele, S., \& Teele, S. C. (2000). Rainbows of intelligence: Exploring how students learn. Corwin Press.

- Wallace, J. (1995). Accommodating elementary students' learning styles. Reading Improvement, 32(1), 38. 